\title{
Financing social protection in Ukraine and the European Union: current situation and prospects
}

\author{
Kseniya Bagmet
}

Ph.D., Ukraine

\section{Hassan Obeid}

\author{
Head of Finance and Accounting Department, European Business School-Paris, France \\ (C) The Authors, 2017. This article is published with open access at ARMG Publishing.
}

\begin{abstract}
The paper analyzes the financial support for social protection in Ukraine compared with European Union countries, in particular the structure and dynamics of social expenditures, their relationship with key macroeconomic indicators were considered. Overall directions of changes in social protection system for bringing about an alignment with the basic European standards were proposed per analysis performed.
\end{abstract}

Keywords: social expeditures, social protection, social support, health care, financing, the European Union.

JEL Classification: H55, H53, I31, I38.

\section{Introduction}

At this stage a full integration of Ukraine into the European Union is complicated by a range of problems, the solution of which is quite long-term as it requires a fundamental change in the socio-economic model of social development. Today, the integration processes in Europe are primarily the processes of social integration, which dictates the need to address the social consequences of any transformations in political, economic and financial spheres. Now the formation of a new model of social protection in Ukraine is the question of the day and, at the same time, is one of the most difficult questions. The difficulty is due to the fact that the level of social security system of population depends not only on operating effect of various social protection mechanisms, but also the whole income distribution system. The latter is extremely controversial and ineffective in Ukraine and its change is slowed by economic crisis and social and political problems.

Provision of a rationale for any changes should be based on a deep analysis of domestic and European model of social protection which allows to identify the gap between us and generate strategic directions for the development of Ukrainian social protection system thereupon. The question of social protection was extensively researched by domestic scientists, including V.D. Bazylevych, V.A. Bezugla, N.M. Vnukova, A.N.V. Kuzmynchuk, R.P. Pidlypna, N.V. Shamanska, L.P. Shapoval, S.I. Yurii, I.S. Yaroshenko and others. However, an absolute answer as to the model whereon it is reasonable for Ukraine to orient in the process of current social protection system reforming and what is the cost of the absence of adequate social policy is not found.

The aim of the article is a comparative analysis of financing social protection in Ukraine and the European Union by key indicators and justification pursuant to the results of directions changes which are appropriate to implement at the present stage of social and economic transformations.

\section{Methods and results of investigation}

It is obvious that European experience should become an example for Ukraine in the formation of social protection model. However, it is necessary to consider the fact that the European social protection is in a state of transformation. Currently, the issues of changing in principles underlying the social protection system in the European Union are raised. The principle of equality underlying the European social and economic model is implemented through this distribution mechanism. Now the departure from orientation to preserving the income level by nonmarket means (through social securities, payments) is actively discussed. Instead, it is proposed to implement policy that encourage the return of socially vulnerable groups into the labor market [3].

This position changes the focus of social policy, which is the principal for financial support mechanisms, as in the case of principle adoption, the nature of social expenditures and income distribution system should be 
changed. The composition of social expenditures, which accounts for domestic and European statistics is significantly different. Expenditure data on social protection and social security and health care provided as a part of Consolidated Budget of Ukraine, which most fully conform with social protection statistics (Social protection statistics - SPS), provided by Eurostat, are analyzed.

The category of social protection and social support in Ukraine includes:

a) social protection in case of incapacity to work;

b) social protection of pensioners;

c) social protection of war and labor veterans;

d) social protection of family, children and young people;

e) social protection of unemployed;

f) assistance in resolving housing problems;

g) social protection of other categories of population;

h) basic and applied researches and development works in social protection;

i) other activities in the field of social protection.

Social protection statistics takes into account the costs associated with the financing of difficult circumstances due to illness (health care), disability, old age, loss of breadwinner, housing problems, and this category of expenditure accounts for assistance to families with children, unemployed workers, and other costs related to social exclusion.

So, considering the absence of expenditures for social protection and social support and assistance connected to illnesses in Ukraine, the health-care expenditures are used in the analysis.

Data on costs provided by the national statistics, would be wiser to adjust for capital expenditures. However, given the lack of official methodological recommendations and small-sized capital expenditures in their structure, adjustments were not made. In addition, health care expenditures are dominated by expenditures on salaries, which can also cause the issue of data comparability, as cited volumes of health care financing in Ukraine concern not only the administrative costs accounted by Eurostat. Conceiving that current structure of financing social expenditures in Ukraine is derived from institutional features, official statistical data are left in the calculations.

Let us analyze the costs of social protection in the EU countries, Ukraine by relative indicators: proportion of GDP and specific social expenditures calculated subject to purchasing power parity (Figure 1, see Appendix).

Figure 1 demonstrates heterogeneity of the EU $\left(E U-28^{1}\right)$ to the share of gross expenditures on social protection in GDP. So, the difference between the highest and the lowest level of costs in GDP in 2014 made 19.8 percentage points - France 34.3\% and Latvia 14.5\%). As it can be seen in Figure 1, there is a positive dependence between the share of expenditures on social protection in GDP and the rate of these expenditures per capita, expressed in purchasing power standards (PPS).

Ukraine shows a significant gap even in comparison with countries that have the lowest share of expenses in GDP and at the same time of relatively low values of social expenditures per capita, calculated based on purchasing power parity (Latvia, Lithuania, Estonia, Romania). Wherein if per the share in GDP the difference is nonsignificant -2.1 percentage points compared with the lowest value, the size of social expenditures per capita in Ukraine will comprise $584.75^{2}$ PPS, which is almost 4 times lower than the lowest value in the EUcountries (2322.88 PPS in Romania).

It is obviously that under such conditions the search for effective mechanisms of financial support for social protection in conjunction with reforming the income distribution in Ukraine is extremely important as ensuring social standards at an appropriate level is dictated by the need for social security of the country and focus on European integration. Then, it should be considered that the European Union tends to increase the expenditures for social protection. Moreover, the EU average growth rate of the latter were higher than the GDP growth [8].

However, the level of expenditures in the EU is heterogenous, so the annual growth rates in the volume of expenditures for EU-28 is significantly affected by changes in Germany, France, Britain and Italy, as these

\footnotetext{
${ }^{1}$ Given the UK, since the analysis is conducted according to the data of 2014.

${ }^{2}$ It is calculated based on the Eurostat's methodology.
} 
four countries together account for two-thirds of the total EU expenditures for social protection. Among them, Italy has demonstrated the lowest average growth rate (0.5\%) for the period 2006-2013, while France had the highest average growth rate (1.5\%) [8].

Social expenditures in Ukraine till 2014 also has positive dynamics (Table 1).

Table 1. Social expenditures in Ukraine in the period 2012-2015

\begin{tabular}{|l|c|c|c|c|c|}
\hline \multicolumn{1}{|c|}{ Indicator } & 2011 & 2012 & 2013 & 2014 & 2015 \\
\hline GDP,mln. UAH & 1349178 & 1459096 & 1522657 & 1566728 & 1979458 \\
\hline $\begin{array}{l}\text { Expenditures on social protection and social } \\
\text { securit, mln. UAH }\end{array}$ & 105555.7 & 125306.9 & 145062.6 & 138004.7 & 176339.8 \\
\hline Share in GDP, \% & 7.8 & 8.6 & 9.5 & 8.8 & 8.9 \\
\hline Expenditures on health protection, mln. UAH & 48961.6 & 58453.9 & 61568.8 & 57150.1 & 71001.1 \\
\hline Share in GDP, \% & 3.6 & 4.0 & 4.1 & 3.6 & 3.6 \\
\hline Total social expenditures, mln. UAH & 154517.3 & 183760.8 & 206631.4 & 195154.8 & 247340.9 \\
\hline Share in GDP, \% & 11.4 & 12.6 & 13.6 & 12.4 & 12.5 \\
\hline $\begin{array}{l}\text { The growth rate of social expenditures } \\
\text { (the previous year) }\end{array}$ & & 1.19 & 1.12 & 0.94 & 1.27 \\
\hline
\end{tabular}

Source: compiled from sources $[4,5]$.

The reduction in funding in 2014 is explained by a difficult socioeconomic situation, fall in GDP due to military activities in the Donbas, annexation of Crimea. However, in 2015 an increase in social expenditures was observed. But considering that the inflation rate (consumer price index) in 2015 year was 124.7 , it can be said that funding of social protection and social support rose slightly, mainly due to the increase in the number of recipients.

The structure of social expenditures is an important aspect of the analysis. The largest component of total expenditures on social protection, which makes about $27.5 \%$ of GDP in the EU-28 is social securities (social and compensatory payments). The size of expenditures on social protection in member states on an average increased by $1.8 \%$ per year in real terms during the period 2006-2012 [8]. The major share of funding, almost $70 \%$, falls on the costs associated with the protection of old people and diseases (Figure 2), while the costs associated with unemployment equals slightly more than 5\%. This occurs on the background of unemployment growth in the period 2006-2012 on an average increased by $2.5 \%$ per year [8].

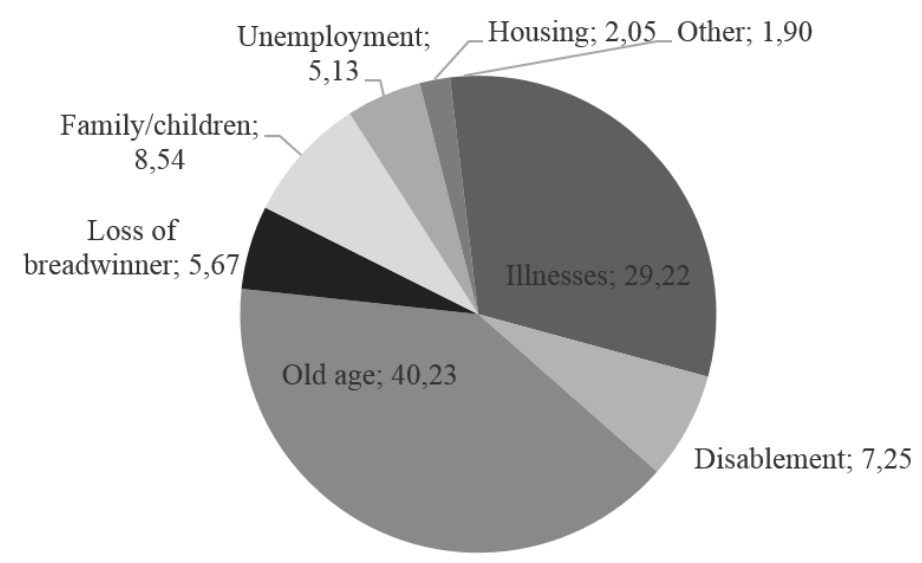

Figure 2. The structure of social protection in the European Union countries (EU-28) in 2014

Source: compiled from source [8].

The predominance of costs associated with the protection of old people is due to demographic situation in Europe. Now measures on remedial actions on demographic changes caused by ageing of population are implemented - 15 member states are pledged to take actions on livelihood support for pensioners and eliminating the deficiency of pension budgets and formation of special funds to finance pension system in the period 20202030 [3].

The share of expenditures on the protection of individuals with housing problems makes $2 \%$, which indicates a significantly higher level of revenues in the EU countries compared to Ukraine. An increase in the amount 
of housing subsidies provided to the residents is observedin Ukraine in 2015. The expenditure level of state budget for housing allowances in 2017 can reach $3.8 \%$ of GDP per different forecasts [2].

The analysis of social expenditures in Ukraine (Table 2) shows that the structure of two categories of expenditures in question - social security and health care - is prevailed over current expenses, which, on the one hand, gives grounds to speak about social orientation of payments, on the other hand, given the institutional features of national health care system, indicates a low level of funding in this area.

Table 2. The structure of social expenditures of Consolidated Budget of Ukraine in the period 2012-2015

\begin{tabular}{|l|c|c|c|c|c|c|c|c|}
\hline \multirow{2}{*}{ Article of expenditures } & \multicolumn{2}{|c|}{2012} & \multicolumn{2}{c|}{2013} & \multicolumn{2}{c|}{2014} \\
\cline { 2 - 8 } & mln. UAH & $\%$ & mln. UAH & $\%$ & mln. UAH & $\%$ & mln. UAH & $\%$ \\
\hline $\begin{array}{l}\text { Total expenditures on social protection and } \\
\text { social security }\end{array}$ & 125306.9 & 100 & 145062.6 & 100 & 138004.7 & 100 & 176339.8 & 100 \\
\hline Current expenditures & 123712.1 & 98.7 & 144301.5 & 99.5 & 137497.5 & 99.6 & 173884.7 & 98.6 \\
\hline Labor expense and charges on payroll & 3817.6 & 3.0 & 4252.9 & 2.9 & 3943.6 & 2.9 & 4069.96 & 2.3 \\
\hline Use of goods and services & 2478.9 & 2.0 & 2444.2 & 1.7 & 2509.6 & 1.8 & 3440.7 & 1.9 \\
\hline Current transfers & 1890.5 & 1.3 & 1872.6 & 1.3 & 1748.5 & 1.3 & 1878.3 & 1.1 \\
\hline $\begin{array}{l}\text { Social security (pensions, allowances, schol- } \\
\text { arships and other payments) }\end{array}$ & 115491.4 & 92.2 & 135690.4 & 93.5 & 129273.5 & 93.7 & 164470.3 & 93.3 \\
\hline Other operating expenses & 33.7 & 0.03 & 41.4 & 0.03 & 22.3 & 0.02 & 25.4 & 0.01 \\
\hline Capital expenditures & 1594.8 & 1.3 & 761.1 & 0.5 & 507.2 & 0.4 & 2455.1 & 1.4 \\
\hline Total expenditures on health care & 58453.9 & 100 & 61568.8 & 100 & 57150.1 & 100 & 71001.1 & 100 \\
\hline Current expenditures & 54489.3 & 93.2 & 57693.8 & 93.7 & 55139.4 & 96.5 & 63943.2 & 90.1 \\
\hline Labor expense and charges on payroll & 36594.98 & 62.6 & 38208.2 & 62.1 & 30858.1 & 54 & 35719.9 & 50.3 \\
\hline Use of goods and services & 16773.8 & 28.7 & 18036.7 & 29.3 & 22598 & 39.5 & 26159.3 & 36.8 \\
\hline Current transfers & 445.1 & 0.8 & 538.0 & 0.9 & 881.8 & 1.5 & 1027.8 & 1.5 \\
\hline Social security & 507.96 & 0.9 & 751.4 & 1.2 & 677.0 & 1.2 & 877.0 & 1.2 \\
\hline Other operating expenses & 167.5 & 0.3 & 159.5 & 0.3 & 124.5 & 0.2 & 159.1 & 0.2 \\
\hline Capital expenditures & 3964.7 & 6.8 & 3874.9 & 6.3 & 2010.7 & 3.5 & 7057.96 & 9.9 \\
\hline
\end{tabular}

Source: compiled from sources $[4,5]$.

A large share of labor expense and use of goods and services in the structure of health care expenditures suggests that financing is still performed on the principle of facilities and institutions retention. However, a departure from this principle is possible only upon condition of development of medical insurance, that needs for reforming the income distribution system. The measures to increase the minimum labor expenses, adopted in 2017, can be considered as a first positive step. However, without further adjustment of income levels, including ensuring that the level of labor expenses corresponds to the qualification of employees, it is impossible to achieve significant improvements in the approach to social standards of the EU, as it is impossible to rely on the formation of the middle class.

In this context authors turn our attention to funding sources of social security, the general structure of which is shown on Figure 3 (see in Appendix).

The main sources of funding of social protection in the EU-28 are social contributions, which account for over half of revenues (55.4\% in 2013) and public (government) funding from taxes (40.4\% in 2013) are depicted in Figure 2. Social contributions include contributions paid by individuals (employees, self-employed persons, pensioners and others) and contributions paid by employers. The latter include two categories of payments:

1) Actual employers' social contribution - social insurance funds, commercial insurance companies, independent pension funds to provide the entitlement to their employees (former employees, their dependants).

2) Imputed employers' social contribution - the costs incurred by employers by granting social benefits or voluntary undertaking to provide a social assistance to their employees, former employees, members of their families without the involvement of an independent insurer in the future without forming certain reserves for this purpose in the balance [6].

The largest share of funding in the total structure belongs to employers $(50.1 \%)$, due to the distribution of social protection systems based on the principle of insurance funding. However, the level of funding for public 
funds is rather significant $40.4 \%$ (Figure 2). This situation is logical, because the data presented describe the structure of financial security for all EU countries. However, there are significant differences between the two countries due to the peculiarities of social protection models that were historically formed in a country. Thus, in the Nordic countries, the Czech Republic, Ireland, etc. public financing of social protection, which is typical for so-called Beveridge model is dominated. For some countries (Germany, France, Belgium, etc.) the insurance principle of social protection systems funding, so-called Bismarck model, is prevalent.

\section{Conclusion}

This analysis showed a significant difference between the level of funding of social protection in the European Union member states and in Ukraine, which requires significant reforms in our country, because integration into European society primarily should be supplemented by significant social progress.

There is also a significant differentiation on the indicators of social protection financing among the member states. On the one hand, it is explained by the level of socioeconomic development of the country, on the second hand, by a social structure, which determines the structure of social expenditures, in the third place, by a model of social protection, historically formed in the country. But today basic principles ensuring an efficient system of social protection were recognized as follows:

1. the interaction of economic, social and employment policy;

2. the regulation of social protection systems and enhancing their role as a productive factor in the development of society;

3. the assessed value of the absence of adequate social policies [7].

Regarding Ukraine, authors consider the principle of regulation as particularly topical and the enhancement of the role of social protection as a productive factor in the development of society, the practical example of which in EU member states is that the full employment is mainly encouraged through an active policy of creation of new jobs in the public sector, especially for women, which ensures a homogeneity of social groups within the middle class.

Once again given analysis confirms that the Ukrainian social security system is a means of poverty reduction. Separate mechanisms for financing costs on social protection and social security are inconsistent and ineffective (housing allowances to the population, etc.). The principles of financing social protection, in particular the rejection of the so-called "precedential" funding principle, strengthening efficiency of social assistance and the like require revisions.

The question of assessed value of adequate social policies should become a compulsory part of studies of social protection and the basis for the model selection, which will be effective for Ukraine.

\section{References}

1. Zvit-monitoryng system socialnych poslyg $\mathrm{v}$ Ukraini [Report-monitoring of social services in Ukraine]. Retrieved from http://bureau.in.ua/downloads/social-reform/reportua.pdf.

2. MinFin: vytraty na subsydii dlia naselenia mozhut' siagnuty $80 \mathrm{mlrd}$.grn. [The Ministry of Finance: the cost of subsidies for the population can reach 80 billion UAH]. Retrieved from http://www.5.ua/ekonomika/minfin-vytraty-na-subsydii-dlia-naselennia-mozhut-siahnuty-do-80-mlrd$\underline{\text { hrn-116477.html. }}$

3. M.V. Karhalova (2011). Socialnaya Evropa v XX veke [Social Europe in XX century]. Moscow, Izdatelstvo Ves' mir. 528 p.

4. Statystychnyi zbirnyk: Biudzhet Ukrainy 2015. Ministerstvo finansiv Ukrainy [Statistical Yearbook: The Budget of Ukraine 2015. Ministry of Finance of Ukraine]. Retrieved from http://www.minfin.gov.ua/uploads/redactor/files/Budget\%20of\%20Ukraine\%202015\%20(with\%20cover).pdf.

5. Statystychnyi zbirnyk: Biudzhet Ukrainy 2014. Ministerstvo finansiv Ukrainy [Statistical Yearbook: The Budget of Ukraine 2014. Ministry of Finance of Ukraine]. Retrieved from http://www. minfin.gov.ua/news/view/statystychnyi-zbirnyk-ministerstva-finansivukrainy-biudzhet--?category= bjudzhet\&subcategory=budget-2014.

6. European system of integrated social protection statistics - ESSPROS. Manual and user guidelines, 2016 edition. Retrieved from http://ec.europa.eu/eurostat/web/products-manuals-and-guidelines-/KS-GQ-16-010. 
7. Grosh M. (2008). For Protection and Promotion: the Design and Implementation of Effective Safety Nets / Margaret Grosh, Carlo del Ninno, Emil Tesliuc, and Azedine Ouerghi. Washington, DC, The World Bank, $587 \mathrm{p}$.

8. Social protection statistics - main indicators. Retrieved from http://ec.europa.eu/eurostat/statistics-explained/index.php/Social_protection_statistics_-_main_indicators.

\section{Appendices}

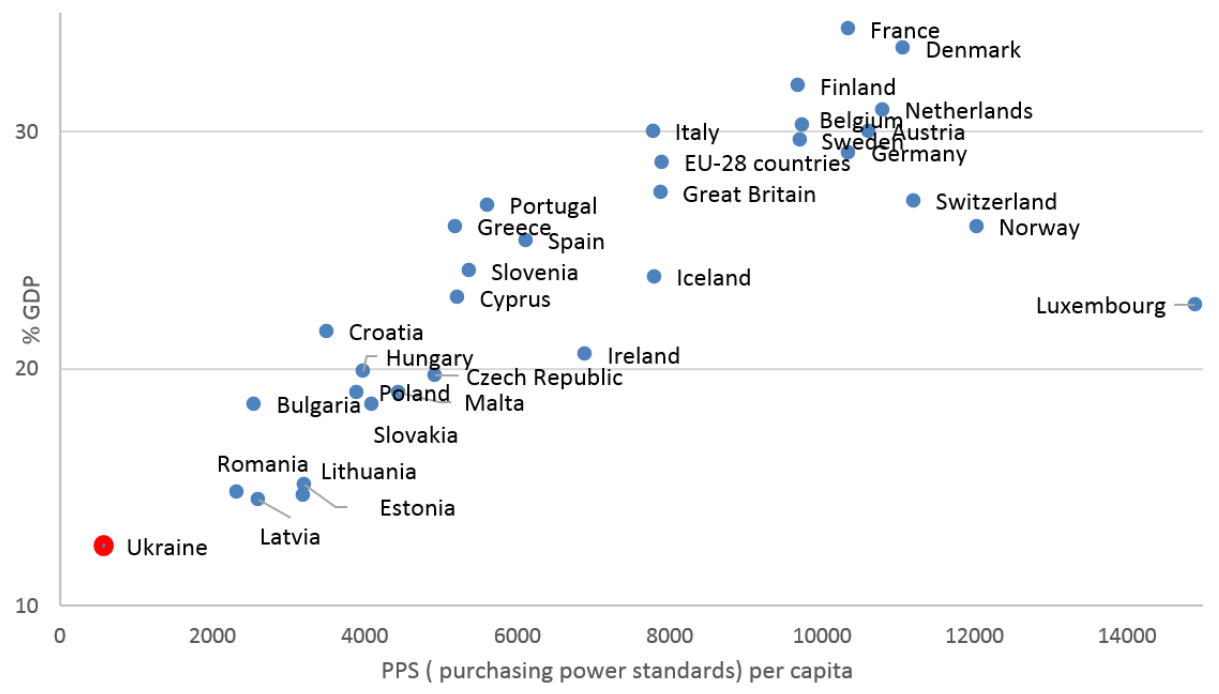

Figure 1. Social expenditures (gross expenditures) in Ukraine and the countries of the European Union in 2014 Source: compiled from source $[4,5,8]$.

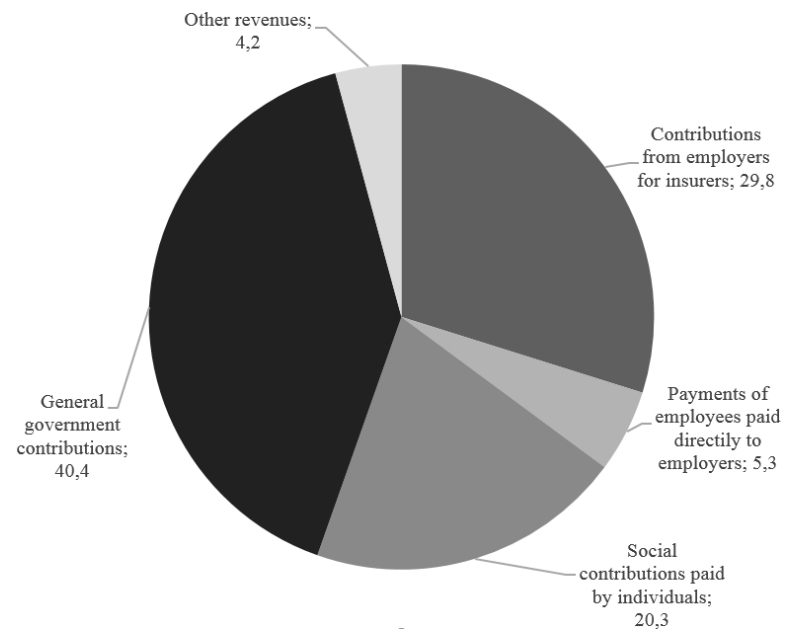

Figure 3. The structure of funding sources of social security in the European union countries in 2013

Source: compiled from source [3]. 